\title{
Benefits of Proximity to Rail on Housing Markets: Experiences in Santa Clara County
}

\author{
Robert Cervero and Michael Duncan \\ Department of City and Regional Planning, \\ University of California
}

\begin{abstract}
$\overline{\text { Abstract }}$
Santa Clara County; California, home to both light-and commuter-rail services, has tumed to transit-oriented development as a means to both reduce traffic congestion and redress severe shortages of affordable housing units. This article examines the degree to which proximity to two forms of rail transit-light rail and commuter railconfer benefits to residential properties in terms of sales values. Hedonic price models are estimated that show job proximity over the transit netwiork as well as nearness to rail stops substantially add value to residential parcels. All else being equal, large apartments within a quarter mile of a light-rail station commanded land-value premiums as high as 45 percent. Such market profits not only lure developers to station sites, but also provide a potential source of revenues to local agencies that have set up the kinds of value-recapture programs that allow them to participate in land-appreciation benefits that accrue.
\end{abstract}

\section{Introduction}

If rail transit investments confer benefits, land markets will tell us. As long as there is a finite supply of parcels near rail stops, those wanting to live or do business near transit will bid up land prices. This article tests this "capitalization" theory using empirical evidence from one of the nation's most congested areas 
and priciest housing markets--Santa Clara County, California, home to Silicon Valley and, within the past decade, three different rail transit systems.

Santa Clara County, the Bay Area's biggest in population (1.68 million) and employment (1.08 million), recently celebrated its tenth anniversary of light-rail services. Much of the past decade was marked by stagnant ridership and steadily worsening traffic congestion. In recent years, however, the region seems to have turned the tide-new rail lines and services have been added, ridership is up, and transit villages are sprouting in different parts of the county.

In 2001, the Tasman West extension was completed, adding 7.6 miles to the initial 21-mile Guadalupe Corridor and linking Santa Clara, Sunnyvale, and Mountain View with downtown San Jose and neighborhoods to the south. In May 2001, the Tasman East line brought light-rail transit (LRT) to Milpitas. serving Cisco System's headquarters and other high-tech campuses. Thanks to recent voter approval of Measure $B$, by a whopping 81 percent margin, a halfcent sales tax is being extended 20 more years to finance billions of dollars in new transit investments, including the extension of the Bay Area Rapid Transit (BART) heavy rail system to downtown San Jose. Few areas around the United States have managed to clear the lofty two-thirds hurdle for extending dedicated transit taxes. Santa Clara County also boasts two commuter-rail services- CalTrain, a commuter-rail service that runs up the peninsula to San Francisco. and the recently opened Altamont Commuter Express (ACE), a conduit to affordable housing in California's Central Valley.

Historically, the County's transit provider, Valley Transit Authority (VTA), has struggled to build a ridership base in part because much of its service territory is a landscape of sprawling office campuses and car-oriented shopping plazas. Extraordinary growth coupled with a beefed-up rail network and a popular employer-paid annual pass program (EcoPass) is starting to make a difference. Between 1998 and 2000, light-rail ridership rose 11 percent and the number of commuter-rail passengers jumped 25 percent. Transit-oriented development (TOD) has also had a hand in coaxing more and more motorists out of cars and into trains.

\section{TODs in the Valley}

Santa Clara County is known internationally as an economic powerhouse of technological innovation and entrepreneurship (Saxenian 1994). Locally, it 
is also known for its woeful shortages of affordable housing (especially near job centers), for having the longest average commute time among workers, and for a low-density, spread-out cityscape that compels residents, workers, and visitors alike to drive cars. From 1995 to 2000, the number of jobs in Silicon Valley grew 4 percent annually yet the number of new homes barely grew 1 percent per annum (Association of Bay Area Governments 2001). In mid-2000, the median single-family home in the Silicon Valley cost $\$ 617,000$, an 87 percent jump from five years earlier.

TOD has been seized upon as a means to attack both housing and transportation problems. Building higher-density units near transit promises to expand the supply of housing while also allowing residents to hop on trains to get to work and other destinations. Few areas of the United States can match the amount of development that has taken place near transit stops in Santa Clara County in the past few years. Between 1997 and 1999, an estimated 4.500 housing units and some 9 million square feet of commercial-office floorspace were added within walking distance of the Tasman West corridor. Planners and builders hope that placing more residents and workers within convenient walking distance of rail stops stations will relieve congestion, promote affordable housing, and improve the jobs-housing balance. Among the instruments introduced to leverage TOD have been tax-exempt financing, public assistance with land assembly, and overlay zones that permit higher densities than the norm.

These incentives appear to be paying off. Mountain View officials recently rezoned 40 acres of industrial land to accommodate more than 500 housing units adjacent to the Whisman LRT station. In Sunnyvale, density bonuses have spurred infill development in the Northside industrial district near the Borregas and Fair Oaks light-rail stations. And Sunnyvale's Moffett Park station, slated to open in 2002 , is to be privately financed. In return for a 60 percent increase in allowable floor area ratio for four high-tech office buildings, the developer, Jay Paul Company of San Francisco, has agreed to foot the bill for the $\$ 2.5$ million project. A 30 -foot wide attractively landscaped walkway will connect the office campus to the station. Not all master-developers have needed lures to attract them to LRT locales, however. The Irvine Company is currently constructing several thousand luxury apartments within walking distance of LRT stations in north San Jose absent any development incentives. 
The availability of large, undeveloped parcels that happened to be near LRT attracted the company's interest.

TODs are even surfacing around commuter-rail stops. Across from the downtown Mountain View station, a 359-unit complex of townhouses, condos, and single-family units, called The Crossings, sits on land once occupied by the Old Mill shopping center. To leverage this development, the City of Mountain View created a Transit Overlay Zone that allowed higher densities, up to a maximum of 50 percent, within 2,000 feet of the station. TODs are also slated for joint commuter-rail/light-rail stations, notably Tamien. In 1995, Santa Clara Valley Transit Authority (SCVTA) sought to jump-start the Tamien TOD by building a day-care center that accommodates 140 children directly on the station site. Besides providing an important service to the nearby community, the center also seeks to promote rail-commuting by making it convenient for parents to drop off and pick up their children each workday.

\section{TOD Benefits}

From a public sector standpoint, the chief benefit of TOD is the prospect of luring people out of cars and into trains and buses. Only then can traffic congestion be relieved and air quality improved. Past studies suggest TODs do just this. Surveys of multifamily complexes near suburban BART stations show as high as 45 percent of those employed take transit to work (Bernick and Cervero 1997). Among those who work in downtown San Francisco and must pay for parking at their workplace, nearly 90 percent do. A 1995 survey by Gerston \& Associates found similar results for light rail-those living near VTA's Guadalupe Corridor commuted by transit five times as often as did residents countywide. These numbers largely represent "self-selection"-those with a natural affinity to hopping on a train to get to work instead of fighting traffic consciously seek out residences within easy walking distance of a station (Gerston \& Associates 1995).

While ridership is the main aim of TOD from a public perspective, the prospect of higher land values and profits is what appeals to private interests. This is because, theory holds, parcels near transit stops enjoy better connectivity, or access--residents can more easily reach jobs and shops; more potential shoppers pass by retail outlets; and for employers, the laborshed of potential workers is enlarged. Since the number of benefiting parcels is 
finite, in a competitive marketplace, households and firms bid for these choice locations, driving up the price of sites.

This article presents research that explores the capitalization effects of proximity to rail transit—both light rail and commuter rail—on residential properties in fast-growing Santa Clara County, California. Besides gauging the degree to which proximity to different forms of rail transit confers benefits to property-owners, there are practical reasons for conducting such research:

- Many developers, and perhaps more importantly lenders, question whether being near transit yields net benefits. Yes, being near a regional rail system enhances accessibility; however in the minds of many, this is offset by the stigma of transit as an inferior form of mobility. TOD is not necessarily a money-making proposition in the minds of some developers.

- Research on transit's capitalization benefits can help assess the degree to which any negative consequences of transit investments are offset by accessibility benefits. Across the country, transit authorities are being sued for severance damages by landowners who claim the incursion of noise, vibration, and increased traffic, as well as partial takings that reduce the usable size of their parcels and diminish property values. In the case of both the BART extension to the San Francisco International Airport and the East Tasman extension, several owners of properties zoned for residential uses have recently charged that the arrival of railtransit services will lower land values. This has placed the onus on transit agencies to produce expert testimony demonstrating that proximity to rail transit confers net benefits to residential properties, expressed in terms of land-value premiums and overall real-estate market performance.

- Evidence of transit's value-added opens up opportunities for joint development and new forms of creative financing (Landis et al. 1991; Cervero 1994). Transit boards are likely to become more entrepreneurial, acquiring vacant parcels near planned rail stations early in the development process, if they believe they can not only reap profits but 
also leverage transit-supportive projects. America has an established and continually expanding track record in this regard. Washington's regional rail authority, Washington Metropolitan Transportation Authority (WMATA), has over the years entered into numerous longterm lease arrangements with developers, recapturing costs not only through rent but also from higher farebox revenues generated by increased activities around stations. In Miami and Denver as well as Washington, transit authorities have leased air rights over transit stations in return for shares of gross revenues received from benefiting commercial properties. In Los Angeles, 9 percent of the $\$ 1.4$ billion spent on the first segment of the Red Line came from benefit assessments levied against commercial properties near rail stations.

Besides these practical reasons, this study was carried out in hopes of filling research gaps and refining our understanding of the influences of contemporary rail investments on land values. Most past studies of capitalization benefits have focused on heavy rail systems; in truth, far more track mileage is being laid for light and commuter rail than for heavy-rail projects in the United States.

Benefits associated with being near transit are thought to be the greatest in fast-growing, congested areas with buoyant and healthy economies. such as Santa Clara County. Because of a booming economy and the aggressive expansion of bus and rail transit services, SCVTA experienced the second highest relative increase in ridership, 136 percent, between 1980 and 2000 (behind San Diego) among transit systems with light-rail services (Dunphy 2001). Between 1999 and 2000 alone, ridership on commuter-rail services to the county jumped 17 percent. ${ }^{1}$ The County's traffic congestion-the worst in the Bay Area, which itself was recently ranked America's second most congested metropolis by the Texas Transportation Institute-is no doubt drawing more and more commuters to buses and trains.

\section{Transit and Residential Property Values}

Is theory on transit's "value-added" borne out by practice? Not totally. Past studies on the impacts of being near rail on residential property values in settings as diverse as Philadelphia, Washington, D.C., Miami, Portland. 
Oregon, and the San Francisco Bay Area have produced mixed results.A study of residential properties near the 14.5-mile Lindenwold Line in Philadelphia concluded that access to rail created an average housing value premium of 6.4 percent (Voith 1993). In a study of three light rail systems (Santa Clara County, San Diego, and Sacramento), a heavy rail system (BART), and a commuter rail system (CalTrain) in California, Landis et al. (1994) found evidence of capitalization effects on single-family housing prices, with heavy rail systems conferring the biggest benefits. Negative externalities from being too near (within 300 meters) of transit were also evident, especially in the case of commuter rail. In the case of the Santa Clara LRT, the authors found single-family homes within 300 meters of a light-rail station with a parking lot were worth around $\$ 31,000$ less than equivalent properties beyond the immediate impact zone of a station, controlling for other factors. Another California study, using matched-pair comparisons of apartment units, found monthly rent premiums on the order of 15 percent for otherwise comparable units within walking distance of a suburban BART station (Cervero 1996).

In contrast to these studies of positive impacts, a study of residential values near the Miami Metrorail system concluded that proximity to rail stations induced little or no relative increase in housing values (Gatzlaff and Smith 1993). Nelson (1992) found that transit accessibility increased home prices in Atlanta's lower-income census tracts but decreased values in upper-income areas. While differences in findings are likely attributable, in part, to local contextual and real-estate market differences, they also likely reflect differences in methodology, measurements, and research design.

\section{Data and Methodology}

To gauge transit's value-added, we turned to Metroscan, a proprietary database that contains information on all real-estate sales transactions recorded in county assessor offices. Records were extracted for residential parcels that sold in 1999, including rental properties and condominiums. Besides coinciding with a buoyant economic period, 1999 was also felt to provide a sufficient time lapse for the benefits of Santa Clara County's light- and commuterrail services, introduced in the early 1990s, to have taken form. In that the benefit of being near transit gets capitalized into the price of land, we opted to statistically examine impacts on parcel values only (exclusive of the value of 
improvements). Assessors generally impute land values by netting out the estimated value of improvements based on the age, type, and quality of structures and assumptions regarding per-square-foot unit costs. To the degree there are errors in assessors' apportionments of values to parcels, there is no reason to believe they are systematically biased in one direction or the other.

For multiunit residential parcels. notably condominiums, the assignment of land values to individual sales can pose measurement problems. In our analysis, land values are imputed by prorating the share of total land area for a condominium project to each unit based on a unit's share of total structure area. Condominiums are such a significant component of Santa Clara County's housing market that ircluding them in the analysis was considered essential. In California, a series of class-action lawsuits holding condominium builders liable for faulty construction as late as 10 years after units were sold has frightened many developers from the condominium housing market. Once a staple in California home construction, condominiums made up only 2,900 units in 1999 (roughly 2 percent of the state's housing production that year) (California Building Industry Association 2001). This contrasts to Santa Clara County. however, where 19 percent of 1999 housing additions were condominiums. There, the market of young professionals drawing attractive salaries and living alone, combined with land constraints and steadily worsening traffic congestion, has produced a ready-made market of condominium dwellers.

We turned to hedonic price models to specify factors that. consistent with traditional real-estate and location theory, influence land values. Hedonic price theory assumes that many goods are actually a combination of different attributes, and that the overall transaction price can thus be decomposed into the component (or "hedonic") prices of each attribute (Rosen 1974; Bartik 1988). Our models took the form:

$\mathrm{P}_{i}=f(\mathrm{~A}, \mathrm{~T}, \mathrm{~N}, \mathrm{C})$

where:

$\mathrm{P}_{i}$ equals the estimated price (per square foot) of parcel $i$.

$A$ is a vector that gauges accessibility of residential properties to job opportunities.

$T$ is a vector gauging proximity to major transportation infrastructure. including light rail and commuter rail transit. 
$N$ is a vector of neighborhood attributes in terms of land uses, income, and racial composition.

$C$ is a vector of controls (e.g., fixed-effect variables).

Variables related to proximity to transit. accessibility, and neighborhood attributes were measured using Geographic Information System (GIS) tools. Both straight-line and network distances were measured to gauge proximity of parcels to transit stations and freeways. Buffers drawn around parcels, ranging in radii from 1 to 5 miles, were digitally overlaid onto block groups and census tracts to estimate neighborhood attributes such as land-use mixes and racial compositions.

\section{Descriptive Statistics}

Basic statistics for the dependent variable, per square-foot residential land value, as well as key predictive variables used in the hedonic price model are presented in Table 1. The average 1999 residential parcel value was over \$20 per square foot, with a fair degree of variation. This high unit value reflects the pent-up demand for affordable housing in and around Silicon Valley; in 1999, the vacancy rate for rental units was a mere 1 percent (Association of Bay Area Governments 2001).

Parcels were generally more oriented toward freeways than transit. Based on the heterogeneity indices used, the typical residential parcel in the database scored fairly highly in terms of the jobs-housing balance within a 5-mile radius and land-use mixture within 1 mile. $^{2}$ Santa Clara County housing units sold in 1999 also tended to be in neighborhoods characterized by racial diversity and also fairly high average household incomes.

\section{Hedonic Price Model Results}

The hedonic price model estimated for predicting residential land values in Santa Clara County in 1999 is presented in Table 2. As in Table 1, explanatory variables are organized into categories. Because values of land were estimated, there was no need to include variables related to building size, quality, age, and other possible attributes of improvements to land. Ordinary least squares (OLS) estimation yielded a statistically significant model that explained 42 percent of the total variation in per square-foot land values across the nearly 7,100 parcels studied. All of the variables in the model were significant at the 5 percent probability level, and most were significant at a 1 percent probability value. 


\section{Table 1}

\section{Descriptive Statistics and Definitions of Variables Used in Hedonic Price Model for Residential Use}

\begin{tabular}{|c|c|c|}
\hline & $\begin{array}{l}\text { Mean or } \\
\text { Proportion }\end{array}$ & $\begin{array}{l}\text { Standard } \\
\text { Deviotion }\end{array}$ \\
\hline Land value Residential parcel land value per square foot (\$1999) & 2030 & 1199 \\
\hline \multicolumn{3}{|l|}{ Accessibility and location } \\
\hline $\begin{array}{l}\text { Regional job accessıbility (hughway) No jobs within } 30 \text { min peak-hour travel time on } \\
\text { highway network }\end{array}$ & 931,908 & 249,696 \\
\hline $\begin{array}{l}\text { Regional job accessibility (transit): No. jobs within } 15 \text { min peak-hour travel time on } \\
\text { transit network }\end{array}$ & 26,212 & 20,130 \\
\hline $\begin{array}{l}\text { Downtown San Jose: Proportion of parceis with } 1 / 2 \text { mile (straight-line) of downtown San } \\
\text { Jose }^{3}\end{array}$ & .002 & 049 \\
\hline \multicolumn{3}{|l|}{ RailHighway proximity } \\
\hline $\begin{array}{l}\text { LRT and large apartment: Proportion of parcels within } 1 / 4 \mathrm{mile} \text { of LRT station and that are } \\
\text { Apartment Complexes ( } 5+\text { units) }\end{array}$ & 002 & .001 \\
\hline Commuter rall Proportion of parcels within $1 / 4$ straight-ine mie of CalTrann station & 007 & 007 \\
\hline $\begin{array}{l}\text { Freeway proximity Distance, in network miles, of parcel to nearest grade-separated } \\
\text { freeway or highway interchange }\end{array}$ & 1.255 & .873 \\
\hline $\begin{array}{l}\text { Freeway disamenity: Proportion of parcels with } 1 / 4 \text { straight-line mile of grade-separated } \\
\text { freeway or highway interchange }\end{array}$ & 043 & 020 \\
\hline \multicolumn{3}{|l|}{ Neighborhood attributes } \\
\hline $\begin{array}{l}\text { Single-family residential Proportion of dwelling units within 1-mile radius of parcel that } \\
\text { are single-family }\end{array}$ & .700 & 164 \\
\hline $\begin{array}{l}\text { Jobs-housing balance: } 1-\{[A B S(E R-E)] /(E R+E)\} \text {, where } \\
E R=\text { employed-residents uithin } 5 \text { mile radius of parcel, } \\
E=\text { employment within } 5 \text { mile radius of parcel }\end{array}$ & .806 & .114 \\
\hline Land-use mux Normalızed Entropy $=\left\{-\Sigma_{\mathbf{k}}\left\{\left(p_{t}\right)\left(\ln p_{1}\right)\right]\right\} /(\ln k)$, where & .676 & .139 \\
\hline \multicolumn{3}{|l|}{$\begin{array}{l}p_{1}=\text { proportion of total land-use activities in category i for } 1 \text {-mile radius of parcel } \\
\text { (where land-use activities are defined in terns of numbers of employed-residents in } \\
\text { single-family housing, employed-residents in multr-family housing, employees in } \\
\text { retail, employees in services, employees in manufacturing, employees in trade, } \\
\text { employees in agnculture, and employees in other (including office sector); and } k=8 \\
\text { (number of land-use categones) }\end{array}$} \\
\hline $\begin{array}{l}\text { Land-use mix and apartments: Land-use mix (Entropy) } \\
\text { Apartment Residential Use }(1=\text { yes, } 0=n \text { o) }\end{array}$ & 039 & 169 \\
\hline $\begin{array}{l}\text { Land-use mix and condommums Land-use mix (Entropy) } \\
\text { Condominum Residental Use (l=yes; } 0 \text {-no) }\end{array}$ & 135 & 282 \\
\hline $\begin{array}{l}\text { Racial mix. normalized entropy }=\left\{-\Sigma_{k}\left[\left(p_{1}\right)\left(\ln p_{1}\right)\right]\right\} /(\ln k) \text {, where: } p_{1}=\text { proportion of } \\
\text { total population in racial category } 1 \text { for } 1 \text {-mile radius of parcel (where racial categories } \\
\text { are White; Afncan American, Asian American; Other; and } k=4 \text { (number of land-use } \\
\text { categories). }\end{array}$ & 714 & .122 \\
\hline $\begin{array}{l}\text { Household income: Mean household income (in \$1999) of households within } 1 \text { mile } \\
\text { radius of parcel }\end{array}$ & 67,318 & 15,598 \\
\hline Housing density No housing units per gross acre withın 1 mule of parcel & 74 & 48 \\
\hline \multicolumn{3}{|l|}{ Residential property attributes } \\
\hline Single-family residential use Proportion & .760 & 431 \\
\hline Condominium use' Proportion & .191 & .355 \\
\hline Condominium lot size (square feet) & 367 & 882 \\
\hline \multicolumn{3}{|l|}{ Munictpality or Census Designated Place Fixed effects } \\
\hline San Jose location Proportion & 710 & .461 \\
\hline Mountain View location Proportion & .013 & .014 \\
\hline Santa Clara location Proportion & 061 & 020 \\
\hline Cupertino Proportion & 033 & .085 \\
\hline G1lroy Proportion & .011 & .012 \\
\hline Burbank Proportion & 003 & .008 \\
\hline Seven Tree: Proportion & 001 & 001 \\
\hline
\end{tabular}




\section{Table 2}

\section{Hedonic Price Model for Predicting Residential Land Values per Square Foot $\mathbf{( \$ 1 9 9 9 )}$ in Santa Clara County, California, 1999}

\begin{tabular}{|c|c|c|c|}
\hline Variable & Coefficient & $\begin{array}{l}\text { Standard } \\
\text { Error }\end{array}$ & $\begin{array}{l}\text { Prob } \\
\text { Value }\end{array}$ \\
\hline \multicolumn{4}{|l|}{ Accessibuluty and location } \\
\hline $\begin{array}{l}\text { Regional job accessibulity (highway) No. jobs (in 100,000s) within } 30 \mathrm{~min} \\
\text { peak-hour travel time on highway network }\end{array}$ & 0836 & 0.000 & .000 \\
\hline $\begin{array}{l}\text { Regional job accessibility (transit) No. jobs (in } 100,000 \text { s) within } 15 \text { min peak- } \\
\text { hour travel time on transit network }\end{array}$ & 29.621 & 0000 & 000 \\
\hline $\begin{array}{l}\text { Downtown San Jose: parcel within } 16 \text { mile straight-line distance of downtown San } \\
\text { Jose }(1=y e s, 0=\text { no) }\end{array}$ & 6547 & 2414 & 007 \\
\hline \multicolumn{4}{|l|}{ RailHighway praximity } \\
\hline $\begin{array}{l}\text { LRT and large apartment. Parcel within } 1 / 4 \text { mile of LRT station }(1=y e s, 0=n o)^{*} \\
\text { Apartment Complex }(5+\text { units) }(1=\text { yes; } 0=\text { no) }\end{array}$ & 9.198 & 4163 & 027 \\
\hline $\begin{array}{l}\text { Commuter rail: Parcel within } 1 / 4 \text { mile (straight-line) of CalTrain station (1=yes; } \\
0=\text { no) }\end{array}$ & 4155 & 1329 & 002 \\
\hline $\begin{array}{l}\text { Freeway Proximity Distance, in netwotk miles, of parcel to nearest grade- } \\
\text { separated freeway or highway interchange }\end{array}$ & -0.500 & 0194 & 010 \\
\hline $\begin{array}{l}\text { Freeway Dis-amenity: Parcel lies with } 1 / 4 \text { mule (straight-line) of grade-separated } \\
\text { freeway or highway interchange }(I-y e s ; 0=n 0)\end{array}$ & -2.725 & 0.565 & .000 \\
\hline \multicolumn{4}{|l|}{ Neighborhood attributes } \\
\hline $\begin{array}{l}\text { Single-family residential: Proportion of dweilıng units within l-mile radius of } \\
\text { parcel that are singie-famly }\end{array}$ & -12.493 & 1.660 & 000 \\
\hline $\begin{array}{l}\text { Jobs-housing balance. } 1-\{\{\mathrm{ABS}(\mathrm{ER}-\mathrm{E})] /(\mathrm{ER}+\mathrm{E})\} \text {, where } \mathrm{ER}=\text { employed- } \\
\text { residents within } 5 \text { mile radius of parcel, } E=\text { employment within } 5 \text { mlle radius } \\
\text { of parce? }\end{array}$ & 2433 & 1.264 & .054 \\
\hline $\begin{array}{l}\text { Land-use mux: Normalized entropy }=\left\{-\Sigma_{k}\left[\left(p_{1}\right)\left(\ln p_{1}\right)\right]\right\} /(\ln k) \text {, where } p_{1}= \\
\text { proportion of total land-use activites in category } 1 \text { for } 1 \text {-mile radius of parcel } \\
\text { (uhere land-use activities are defined in terms of numbers of employed- } \\
\text { residents in single-family housing; employed-residents in multi-famly } \\
\text { housing, employees in retail, employees in services, employees in offices; } \\
\text { employees in trade, employees in agnculture, and employees in other } \\
\text { (mcluding office sector); and } k=8 \text { (number of land-use categories) }\end{array}$ & 12483 & 1.659 & 000 \\
\hline $\begin{array}{l}\text { Land-use mix and apartments: Land-use mix (Entropy) }{ }^{*} \\
\text { Apartment Residential Use }(1=y e s, 0=\text { no) }\end{array}$ & -15.707 & 4.896 & 001 \\
\hline $\begin{array}{l}\text { Land-use Mix and condomums. Land-use mix (Entropy)* } \\
\text { Condomum Residential Use (1=yes; } 0=\text {-no) }\end{array}$ & 4398 & 2.236 & 049 \\
\hline $\begin{array}{l}\text { Racial mix. Normalized entropy }=\left\{-\Sigma_{k}\left[\left(p_{1}\right)\left(\text { ln } p_{1}\right)\right]\right\} /(\ln k) \text {, where } p_{1}= \\
\text { proportion of total population in racial category } 1 \text { for } 5 \text {-mile radius of parcel } \\
\text { (where racial categories are: White; Afncan American; Asian American; } \\
\text { Other; and } k=4 \text { (number of land-use categones). }\end{array}$ & -12657 & 2187 & 000 \\
\hline $\begin{array}{l}\text { Household income Mean household income (in \$10,000, 1999) of households } \\
\text { within i-mile radius of parcel }\end{array}$ & 1.542 & 0.001 & .000 \\
\hline $\begin{array}{l}\text { Housing density. No. housing unuts per gross acre within } 1 \text {-mile radius of parcel } \\
\text { Residential property attributes }\end{array}$ & -0.101 & 0000 & .000 \\
\hline Single-family residentral use: (1=yes; $0=n o)$ & -7716 & 3.751 & 040 \\
\hline Condominum use: ( 1 -yes, 0 -no) & 16039 & 4.015 & 000 \\
\hline Condominium lot size (in 1,000 square feet) & -6.149 & 0000 & .000 \\
\hline \multicolumn{4}{|l|}{ Municipality fuxed effects } \\
\hline San Jose location ( $1=$ yes; $0=n o)$ & 2.011 & 0.355 & .000 \\
\hline Mountain View location (1=yes, $0=$ no $)$ & 4721 & 1006 & .000 \\
\hline Santa Clara location (1=yes, $0=$ no) & 1858 & 0.568 & .001 \\
\hline Cupertino (1=yes; 0 -no) & 5308 & 0689 & 000 \\
\hline Gilroy $(1=y e s ; 0=n o)$ & 4800 & 1.230 & 000 \\
\hline Burbank ( $1=$ yes; 0 -no) & 4682 & 1934 & 015 \\
\hline Seven Tree $(1=$ yes; $0=$ no $)$ & -5.913 & 3101 & 057 \\
\hline Constant & 11.689 & 4585 & .011 \\
\hline $\begin{array}{l}\text { Summary Statistics } \\
\text { No. observations }=7,098 \\
\text { F Statıstuc (prob.) }=209.136(.000) \\
\text { R-Squared }=.425\end{array}$ & & & \\
\hline
\end{tabular}




\section{Proximity to Transit}

Table 2 lends credence to the real-estate industry's "location, location. location" cliché. Location clearly matters when it comes to Santa Clara County's residential land market. The table shows that accessibility of residential parcels to jobs-both over the highway and transit networks-increased land values, as did nearness to the County's central business district, all else being equal. In fact, greater benefit was attached to proximity to jobs over the transit network (defined over a 15-minute isochrone) than over the highway network (defined over a 30-minute isochrone). From the model's coefficient, one can infer that every 100,000 additional jobs that were within a 15-minute travel time of the Valley's transit system increased residential land values by almost $\$ 30$ per square foot, ceteris paribus. Clearly, having good transit connectivity to employment opportunities in a highly congested locale like Santa Clara County gets rewarded in terms of residential property values.

Table 2 also reveals that substantial capitalization benefits accrued to residential parcels within a quarter-mile distance (what often corresponds to a 5minute walking distance) of a rail-transit station. In the case of light rail, this only held for land zoned for and used for apartments of five units or more, however. Parcels zoned for large apartments that were within a quarter-mile distance of light-rail stops commanded a value premium of around $\$ 9$ per square foot. Compared to the mean parcel value of $\$ 20.30$, this translates into an overall land-value premium associated with proximity to rail of 45 percent. Relative to all residential parcels that are within 4 miles of a light-rail station. the capitalization premium was 28 percent.

In contrast to the findings for light-rail transit, being near a commuter-rail station conferred value benefits to all types of residential parcels-single-family units as well as small and large apartment properties. Land-value premiums for commuter rail, however, were not even half as high as those for light-rail transit, though they were substantial-above 20 percent-just the same. Clearly, in a traffic-snarled landscape with severe shortages of affordable housing, being close to a commuter-rail line makes residential parcels more attractive, which in turn bids up land values.

Relationships were opposite from those of a separate analysis we did of capitalization effects on commercial properties in Santa Clara County (Cervero and Duncan 2002). In that study, proximity benefits were higher for commuter 
rail than light rail. This suggests that the effects of transit on land markets could be highly differentiated (i.e., capitalization benefits conferred by different types of transit differ among land uses).

Table 2 also shows there was a value in being near freeways--all else being equal, land values fell by fifty cents per square foot for every mile (measured over the highway network) away from a freeway. Being too close to a freeway, however, depressed values, due to the disamenity effect (i.e., negative externalities, like noise, fumes, vibration, and head-light glare). No such disamenity effect was found in the case of transit.

\section{Neighborhood Effects and Other Controls}

The model also provides other perspectives into neighborhood land-use attributes that confer value to residential properties. Mixed-use and balanced neighborhoods-attributes that are embraced in TOD design models-add considerable value to residential parcels as well. Having a balance of jobs to employed-residents within 5 radial miles of a residential parcel meant properties were generally worth significantly more. Clearly, in a county known for being job-rich and housing-poor, residential land markets capitalize the benefits of balanced growth. Similarly, land-use mix--as expressed by a normalized entropy variable for land uses within 1-mile radii of parcels-was found to increase per square-foot land values for residential parcels, ceteris paribus. All else being equal, a parcel in a neighborhood with maximal mix (reflected by an entropy score of 1) could be expected to fetch around $\$ 12.50$ per square foot more in the open market than a comparable one in a single-use neighborhood (reflected by an entropy score of 0 ). The interactive terms used in the analysis revealed that being in a mixed-use neighborhood conferred proportionally greater benefits to for-sale high-density units (i.e., condominium properties) and lower benefits to rental apartments.

Quality of neighborhood, as reflected by the proxy variable, mean household income within a 1-mile radius, was associated with relatively high residential land prices. Nearby housing densities, on the other hand, tended to deflate them. While neighborhood land-use diversity was positively associated with residential values, racial diversity tended to have the opposite effect. For two residential parcels identical in all other respects, the one in a maximally racially diverse neighborhood (reflected by a normalized entropy value of 1 ) 
could be expected to sell for over $\$ 12$ per square foot less than one in a maximally homogenous one (reflected by a value of 0 ). Exclusionary zoning has been accused of segregating neighborhoods in urbanized California (Fulton 1999); thus, this finding could reflect the fact that minorities have historically been kept out of middle-income neighborhoods through strategies like large-lot zoning.

The model in Table 2 also shows a number of fixed-effect control variables were statistically significant, capturing unique attributes of municipalities that have a bearing on property values, such as quality of local schools. Control variables representing type of residential uses generally show higherdensity housing commands more revenues per square foot, reflecting their greater profit potential. Condominiums generally reaped land-value premiums (as prorated to each unit based on its share of total structure area), though this generally diminished with the size of the condominium project.

\section{Shaping Policy}

In a red-hot real-estate market like Santa Clara County, proximity of residential parcels to rail transit-both light and commuter rail-was found to matter. The high land-value premium commanded by light-rail transit suggests that an intracounty transportation system-even one that shares right-of-way with regular highway traffic-- can be a strong income-producer and city-shaper when traffic congestion gets bad enough. While transit's capitalization benefits have been questioned in other parts of the United States, the value-added to Santa Clara's residential land market is appreciable and unmistakable.

These findings should be welcomed by residential property-owners with holdings near rail stops and transit agencies trying to fend off legal suits by those who claim they are harmed by transit's presence. Local governments should also take note. Under the right conditions, they stand to capture some of the value-added produced by public investment in transit, either indirectly through increased property tax proceeds or directly through joint development initiatives. As practiced in the United States, joint development can take many forms, such as localities or transit agencies purchasing, holding and leasing land on the open market, air-rights leasing, benefit assessment districts, and station-connection charges (for the right of retail shops to extend passageways to concourses in hopes of grabbing pass-by traffic) (Landis et al. 1991). 
To date, the WMATA has pursued joint development as aggressively as any U.S. transit authority. Value-capture is a core principle of the organization. Rather than waiting and reacting to developer proposals, WMATA's real-estate office actively seeks out mutually advantageous joint-development opportunities. With financial and institutional support provided by board members, WMATA's real-estate office has over time amassed an impressive portfolio of land holdings, much of it purchased on the open marketplace. Today, WMATA's joint development projects run the gamut between revenue-producing schemes (e.g., air-rights leasing, station-retail connections) to cost-sharing arrangements (e.g.. shared use of heating systems, construction-cost coventuring). As of 1999, WMATA had undertaken 27 development projects at a value of more than \$2 billion on land they own (McNeal and Doggett 1999). The agency reaps over $\$ 2$ million annually in air-rights income from two projects alone-mixed-use buildings at the Bethesda and Ballston stations (Bernick and Cervero 1997).

Most recently. WMATA has exploited the Federal Transit Administration's new joint development rulings. The new rules allow transit agencies to sell land (e.g.. formerly used for surface parking) purchased using Federal grants as long as they maintain "sufficient continuing control over the property to ensure its continued physical or functional relationship to transit." However, this control can be achieved in many indirect ways, such as through an easement. Recently, WMATA sold a parcel it owned next to the Grosvenor station at a handsome profit to a developer of a large-scale housing project, maintaining an easement for transit use. Because the agency controlled access, it was able to retain all proceeds from the land sale.

Recapturing value is particularly important where TOD is being pursued. TODs often require a lot of upfront improvements and amenities to jump-start the development process. The responsibility often falls on cash-strapped municipalities to take the lead in attracting private capital to rail station areas by "sprucing up" the neighborhood-through generous landscaping, sidewalk improvements, and in riskier settings, underwriting land acquisitions costs. All of this takes money, often lots of it. Thus, value capture provides a source of funds not only to help pay off the debt on transit investments but also to cover the cost of upfront ancillary improvements that can help kick-start a TOD. 
The study findings also inform the practice of land-use planning in fastgrowing settings like Santa Clara County. Proximity to jobs is important to residents. Higher concentrations of jobs within a 15 -minute travel time by transit and 30-minute time by car led to higher residential land values. This hints at a pent-up demand for niche-market housing in traffic-clogged high-tech settings (e.g.. housing targeted at young, childless professionals willing to give up living space in return for good job access). Being near consumer services also adds value, suggesting a market demand for particular combinations of urban activities. That mixed uses also yield public benefits is icing on the cake. Studies show that having eateries and day-care centers near employment sites. especially those served by rail transit, can boost ridership since workers can more easily consolidate trip ends and take care of midday affairs (like lunching at a restaurant) without a car. To the County's credit, its Congestion Management Agency has adopted a policy of reducing estimated car trips when assessing the impacts of new projects near rail transit and in mixed-use settings, a practice known as sliding-scale impact fees. Ultimately, county leaders believe that smarter calculations will lead to smarter growth.

\section{Endnotes}

1. Between 1999 and 2000, ridership on the Altamont Commuter Express (ACE) to San Jose increased 66.1 percent and ridership on CalTrain. a commuter-rail service that connects downtown San Francisco and downtown San Jose and operated by the Peninsula Corridor Joint Powers Board, increased 14.2 percent. See: http://www.transact.org/ca/ridership_chart.htm.

2. The balance indicator yields a value of 0 , signifying complete imbalance, when either ER (employed residents) or $\mathrm{E}$ (employment) equals zero; a value of 1 , signifying complete equanimity, occurs when $\mathrm{ER}=\mathrm{E}$. The normalized entropy index takes on a value of 0 (maximum homogeneity) when all land uses are in a single category and 1 when land uses are equally spread across all categories (maximum heterogeneity).

3. The center of downtown San Jose was treated as a point midway between 1st and 2nd Streets along Santa Clara Street. 


\section{References}

Association of Bay Area Governments. 2001. Silicon Valley Projections 2000. Oakland: Association of Bay Area Governments.

Bartik. T. 1988. Measuring the benefits of amenity improvements on hedonic models. Land Economics, 64(2): 172-183.

Bernick. M., and R. Cervero. 1997. Transit villages for the 21 st century: New York: McGraw-Hill.

California Building Industry Association. 2001. Where will they live? Sacramento: California Building Industry Association.

Cervero. R. 1994. Rail transit and joint development: Land market impacts in Washington. D.C., and Atlanta. Joumal of the American Planning Association, 60 (1): 83-94.

Cervero. R. 1996. California's transit village movement. Journal of Public Transportation. 1(1): 103-130.

Cervero. R.. and M. Duncan. 2002. Transit's value-added: Effects of light- and commuter-rail services on commercial land values in Santa Clara County, California. Transportation Research Record (forthcoming).

Dunphy. R. 2001. Transit trends. Urban land, 60(5): 79-83.

Fulton, W. 1999. Guide to California planning. Point Arena, CA: Solano Press Books.

Gatzlaff, D., and M. Smith. 1993. The impact of the Miami Metrorail on the value of residences near station locations. Land Economics, 69(1): 54-66.

Gerston \& Associates. 1995. Transit-based housing. San Jose: Prepared for the Santa Clara County Transportation Agency and the Santa Clara Valley Manufacturing Group.

Landis, J., R. Cervero, and P. Hall. 1991. Transit joint development in the USA: An inventory and policy assessment. Environment and Planning C, 9(4): $431-452$. 
Landis, J., S. Guathakurta, and M. Zhang. 1994. Capitalization of transportation investments into single-family home prices. Institute of Urban and Regional Development, University of California, Berkeley. Working Paper 619.

McNeal, A., and R. Doggett. 1999. Metro makes its mark. Urban Land, 58 (9): 78-81, 118.

Nelson, A. 1992. Effects of elevated heavy-rail transit stations on house prices with respect to neighborhood income. Transportation Research Record 1359: $127-132$.

Rosen, S. 1974. Hedonic prices and implicit markets: Product differentiation in pure competition. Journal of Political Economics. 82: 34-55.

Saxenian, A. 1994. Regional advantage: Culture and competition in Silicon Valley and Route 128. Cambridge, MA: Harvard University Press.

Voith, R. 1993. Changing capitalization of CBD-oriented transportation systems: Evidence from Philadelphia, 1970-1988. Journal of Urban Economics, 33: 361-376.

\section{About the Authors}

ROBERT CERIERo (robertc@uclink.berkeley.edu) is professor of city and regional planning at the University of California, Berkeley.

Michael DunCaN (dunc@uclink.berkley.edu) is a doctoral student in Berkeley's planning program. 